\title{
Agro Waste Utilization for Cost-Effective Production of L-Asparaginase by Pseudomonas plecoglossicida RS1 with Anticancer and Acrylamide Mitigation Potential
}

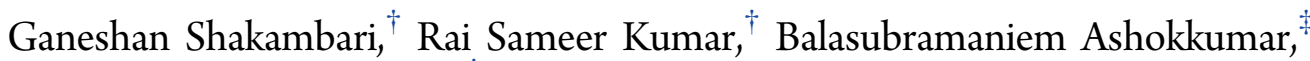 \\ and Perumal Varalakshmi* ${ }^{* \dagger}$
}

${ }^{\dagger}$ Department of Molecular Microbiology, School of Biotechnology, and ${ }^{\ddagger}$ Department of Genetic Engineering, School of Biotechnology, Madurai Kamaraj University, Madurai, Tamil Nadu 625021, India

\section{Supporting Information}

\begin{abstract}
Agricultural wastes such as the peels of onion and garlic were used as a supplement along with L-asparagine for the very first time to produce increased yield of L-asparaginase by Pseudomonas plecoglossicida RS1. Statistical optimization strategies such as response surface methodology were used to generate a medium composition containing extracts of $0.9(\mathrm{v} / \mathrm{v})$ of garlic peel waste and $0.5 \%(\mathrm{v} / \mathrm{v})$ onion peel waste along with $0.2 \%(\mathrm{w} / \mathrm{w})$ L-asparagine, which yielded a twofold increase in the enzyme activity compared to the unsupplemented minimal (M-9) medium. The presence of L-asparagine content in the peel extract was confirmed by high-performance liquid chromatography. Further, L-asparaginase was purified to homogeneity, and identity was confirmed by matrix-assisted laser desorption ionization time-of-flight analysis. The application of the purified L-asparaginase as a therapeutic was studied in $\mathrm{HeLa}$ cells which showed a p53-mediated $\mathrm{G}_{2}$ cell cycle arrest. Moreover, the purified L-asparaginase showed effective acrylamide mitigation in vitro, at $6 \mathrm{IU}$, and its effective degradation was also demonstrated by the effect on chemotactic index of Caenorhabditis elegans and the restoration of the cognitive abilities of C. elegans which was coexposed to acrylamide and Lasparaginase compared to that exposed to acrylamide alone. Thus, L-asparaginase, with multipotent applications, was produced by effective waste utilization for economical commercial production.

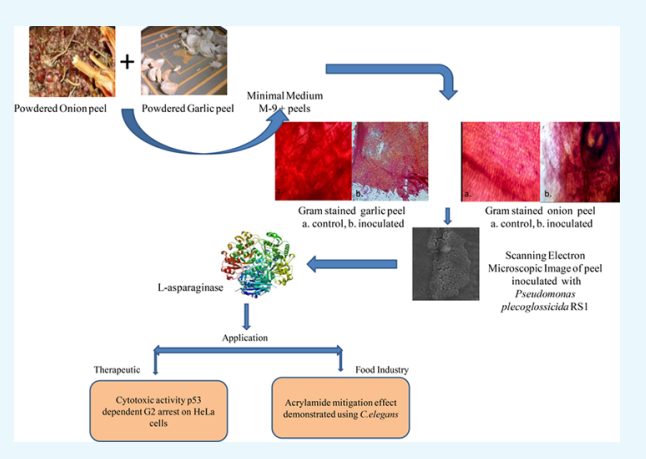

\section{INTRODUCTION}

India being an agricultural nation, it is a resource hub for generating agro wastes, and till the year 2015, reports observe that 1500 lakh ton agro waste was produced in India every year. Hence, if such wastes could be deployed as a useful media component for the development of a commercially valuable product, it would further boost economical production and facilitate waste remediation. In some cases, preconsumer organic wastes have been used for the production of garbage enzyme, which finds an application in antimicrobial agents and treatment of domestic, municipal, and industrial wastes. ${ }^{1}$ To enhance the production of many such important enzymes, various wastes have been used as an alternative substrate, such as municipal solid wastes, sugar industry wastes, and even agro wastes such as corncob. ${ }^{2-4}$

One such important enzyme, L-asparaginase, has been used commercially in therapeutics and in the food industry for its ability to catalyze the conversion of $\mathrm{L}$-asparagine to L-aspartic acid and ammonia. Various bacterial and fungal sources have been known to produce L-asparaginase; however, the commercial production of this enzyme by these organisms using cheaper substrates is of considerable interest to researchers. 
Further, the purified enzyme L-asparaginase was prospected for its multipotent applications as an anticancer agent on human cervical cancer cells, and its acrylamide mitigation ability was studied using live animal model Caenorhabditis elegans.

\section{RESULTS AND DISCUSSION}

Production of L-Asparaginase by Pseudomonas plecoglossicida RS1 Using M-9 Medium Supplemented with Onion and Garlic Peels. The production of Lasparaginase on a commercial scale is a matter of interest because of its therapeutic applications as an anticancer agent. Hence, various alternative cheaper substrates have been prospected for the commercial production of L-asparaginase, including industrial effluent, ${ }^{2}$ corncob, ${ }^{3}$ coconut oil cake, and leguminous crops. ${ }^{12}$

Onion and garlic peels have hitherto been used as an alternative source of inulin for the increased production of inulinase by solid-state cultivation. ${ }^{13}$ Other than inulin, onion peels are rich in phenolic compounds and flavonoids such as quercetin, ${ }^{14}$ and its wastes (onion skin) are frequently utilized as a cheap adsorbent for decontamination purposes and an alternative for the treatment of wastewaters. ${ }^{15}$ Furthermore, phenolic compounds such as quercetin and vanillic acids have been reported to influence the enzyme activity of arginine deiminase to increase about $37-40 \%$ higher, and thus the effect of phenolic compounds in enzyme metabolism cannot be understated. ${ }^{16}$ Moreover, onion peel and garlic peel contain many such polyphenolic compounds and sulfur-containing compounds including S-allylcysteine sulfoxide (alliin; characteristic of garlic), ajoene, and $S$-allylcysteine. Such compounds may facilitate the induction of certain specific enzymes, alliinase (EC 4.4.1.4), which cleaves the above precursors to give pyruvate, ammonia, and thiosulfinate. ${ }^{17}$ Substances in purified alliin and those related to alliin were determined by highperformance liquid chromatography (HPLC) mass spectrometry(MS)/MS by Liakopoulou-Kyriakides et al. in $(1985)^{18}$ and Yuan et al. (2007), ${ }^{19}$ and they were identified as proline, asparagine, glutamine, methionine, arginine, isoalliin, and cycloalliin. Because of the presence of such components, it may be proposed that allium may induce the production of $\mathrm{L}$ asparaginase, which breaks down L-asparagine to aspartic acid and ammonia similar to alliinase. In this study, onion and garlic peels were subjected to bacterial degradation by $P$. plecoglossicida RS1 in M-9 medium (Supporting Information, Table S1) and the peels from the culture media (M-9 OG medium) were subjected to scanning electron microscopy (SEM) analysis.

SEM of the Fragments of Peels in M-9 OG Medium. The M-9 medium was cultivated with $P$. plecoglossicida RS1 for $48 \mathrm{~h}$ at $37^{\circ} \mathrm{C}$, and the peel fragments were sputter-coated with gold particles and observed with the help of a scanning electron microscope (Supporting Information, Figure S1). Uninoculated OG medium was used as a control. The adherence of the bacteria onto the peels and the corresponding degradation of the peels were visually evidenced. Thus, the utilization of the wastes for their effective remediation was also proved using the dried peel powder.

Hence, these peels were used in this study to increase the production of L-asparaginase. It was observed by previous experiments performed that garlic peels alone or onion peels alone, for L-asparaginase production, did not show any significant increase in neither enzyme activity nor specific activity (data not shown). Further, when the peels were used as a supplement along with $0.3 \mathrm{w} / \mathrm{v} \%$ of $\mathrm{L}$-asparagine (Supporting Information, Table S1), maximum enzyme activity was observed.

HPLC Analysis of OG Peel Extracts. HPLC analysis of the peel extracts revealed the presence of $\mathrm{L}$-asparagine in garlic peels, showing peaks [retention time (RT) -5.047 and 5.382] at the same RT as standard L-asparagine (RT-5.024 and 5.360). Earlier reports of HPLC of L-asparagine similarly showed a RT at $5.8 \mathrm{~min}^{13}$ Onion peels also showed the retention peaks at a nearly similar time (RT-5.172 and 5.442), however, in lesser quantity (14\%) than that in garlic peels (20\%) (Supporting Information, Figure S2). Therefore, the peels extracted in potassium phosphate buffer were used as a supplement along with L-asparagine to enhance $\mathrm{L}$-asparaginase production by $P$. plecoglossicida RS1.

In the analysis for enzyme production, both higher enzyme yields along with higher protein content were obtained when $1 \%(\mathrm{v} / \mathrm{v})$ of peel extract was used along with $0.3 \% \mathrm{~L}$-asparagine (Table 1). Hence, CCD was made, and RSM was undertaken to study the interaction between the onion peel $(0.5 \mathrm{v} / \mathrm{v} \%)$ and garlic peel extract $(0.5 \mathrm{v} / \mathrm{v} \%)$ and L-asparagine $(0.2 \mathrm{w} / \mathrm{v}$ $\%)$.

Table 1. Screening of L-Asparaginase Production in M-9 Media Containing Agro Waste Extracts as a Supplement with $0.3 \mathrm{~g} / 100 \mathrm{~mL}$ L-Asparagine, by $P$. plecoglossicida RS1

$\begin{array}{llcc} & \begin{array}{c}\text { peel extracts } \\ (\mathrm{v} / \mathrm{v})\end{array} & \begin{array}{c}\text { enzyme activity } \\ (\mathrm{IU} / \mathrm{mL})\end{array} & \begin{array}{c}\text { protein } \\ (\mathrm{mg} / \mathrm{mL})\end{array} \\ \begin{array}{c}\text { no peels } \\ (0.3 \% \text { asparagine })\end{array} & 0 & 0.522 \pm 0.041 & 0.486 \pm 0.032 \\ \mathrm{OG}^{a} & & & \\ & 0.1 & 0.014 \pm 0.050 & 0.575 \pm 0.040 \\ & 0.25 & 0.158 \pm 0.005 & 0.629 \pm 0.100 \\ & 0.5 & 0.183 \pm 0.046 & 0.754 \pm 0.042 \\ & 0.75 & 0.187 \pm 0.021 & 0.829 \pm 0.032 \\ \mathrm{AOG}^{a} & 1 & 0.256 \pm 0.042 & 0.916 \pm 0.037 \\ & 0.1 & 0.502 \pm 0.045 & 0.459 \pm 0.040 \\ & 0.25 & 0.634 \pm 0.040 & 0.441 \pm 0.036 \\ & 0.5 & 0.736 \pm 0.063 & 0.711 \pm 0.087 \\ & 0.75 & 0.975 \pm 0.125 & 0.905 \pm 0.083 \\ & 1 & 1.090 \pm 0.079 & 1.349 \pm 0.030\end{array}$

${ }^{a} \mathrm{OG}-$ onion and garlic peel extracts and AOG-asparagine (0.3\%) along with onion and garlic peel extracts.

RSM-Based Study of Parameters Critical to the Production of L-Asparaginase by P. plecoglossicida RS1 in a Medium Supplemented with Onion Peel and Garlic Peel Extracts. CCD with the three factors viz., concentrations of the extract of onion peel, garlic peel extract, and L-asparagine, with the central values as $0.5 \mathrm{v} / \mathrm{v} \%, 0.5 \mathrm{v} / \mathrm{v} \%$, and $0.2 \mathrm{w} / \mathrm{v} \%$, respectively, was made, and its results are given in Table 2 . It is evident from Table 2 that the observed values of enzyme activity were very close to the values predicted by the DesignExpert software, for the given design of the study. Further, it is evident that maximum enzyme production was achieved in run 12 with $0.5 \mathrm{v} / \mathrm{v} \%$ of onion peel extract, $0.92 \mathrm{v} / \mathrm{v} \%$ of garlic peel extract, and $0.2 \mathrm{w} / \mathrm{v} \% \mathrm{~L}$-asparagine.

It is of considerable interest to note the ANOVA analysis (Supporting Information, Table S2), which shows the model $p$ value to be significant $(<0.005)$ and model $F$-value of 7.9 , which implies that the value is significant and there is just $0.19 \%$ chance that this large value could be due to noise. Thus, the noise value is least for the model. The $R^{2}$ value $(0.597)$ and the 
Table 2. RSM Employed for the Optimization of Medium with OG Extract and L-Asparagine, with the Predicted and Observed Response Values of Enzyme Activity (IU/mL) of L-Asparaginase Produced by P. plecoglossicida RS1

\begin{tabular}{|c|c|c|c|c|c|}
\hline \multirow[b]{3}{*}{ std } & \multirow{3}{*}{$\frac{\text { factor } 1}{\text { A: onion peel } \%(v / v)}$} & \multirow{3}{*}{$\frac{\text { factor } 2}{\text { B: garlic peel } \%(v / v)}$} & \multirow{3}{*}{$\frac{\text { factor } 3}{\text { C: } \text { L-asparagine } \%(\mathrm{w} / \mathrm{v})}$} & \multirow{2}{*}{\multicolumn{2}{|c|}{$\frac{\text { response }}{\text { enz. activity }(\mathrm{IU} / \mathrm{mL})}$}} \\
\hline & & & & & \\
\hline & & & & observed & predicted \\
\hline 1 & 0.25 & 0.25 & 0.15 & 0.552 & 0.503 \\
\hline 2 & 0.75 & 0.25 & 0.15 & 0.693 & 0.621 \\
\hline 3 & 0.25 & 0.75 & 0.15 & 0.738 & 0.824 \\
\hline 4 & 0.75 & 0.75 & 0.15 & 0.952 & 0.942 \\
\hline 5 & 0.25 & 0.25 & 0.25 & 0.598 & 0.516 \\
\hline 6 & 0.75 & 0.25 & 0.25 & 0.554 & 0.634 \\
\hline 7 & 0.25 & 0.75 & 0.25 & 0.552 & 0.837 \\
\hline 8 & 0.75 & 0.75 & 0.25 & 1.036 & 0.955 \\
\hline 9 & 0.08 & 0.5 & 0.2 & 0.764 & 0.630 \\
\hline 10 & 0.92 & 0.5 & 0.2 & 0.771 & 0.828 \\
\hline 11 & 0.50 & 0.08 & 0.2 & 0.465 & 0.459 \\
\hline 12 & 0.50 & 0.92 & 0.2 & 1.246 & 0.999 \\
\hline 13 & 0.50 & 0.5 & 0.12 & 0.766 & 0.718 \\
\hline 14 & 0.50 & 0.5 & 0.28 & 0.935 & 0.740 \\
\hline 15 & 0.50 & 0.5 & 0.2 & 0.667 & 0.729 \\
\hline 16 & 0.50 & 0.5 & 0.2 & 0.676 & 0.729 \\
\hline 17 & 0.50 & 0.5 & 0.2 & 0.676 & 0.729 \\
\hline 18 & 0.50 & 0.5 & 0.2 & 0.624 & 0.729 \\
\hline 19 & 0.50 & 0.5 & 0.2 & 0.643 & 0.729 \\
\hline 20 & 0.50 & 0.5 & 0.2 & 0.672 & 0.729 \\
\hline control (M-9 + 0.3\% Asn $)$ & 0 & 0 & 0.3 & 0.600 & \\
\hline
\end{tabular}
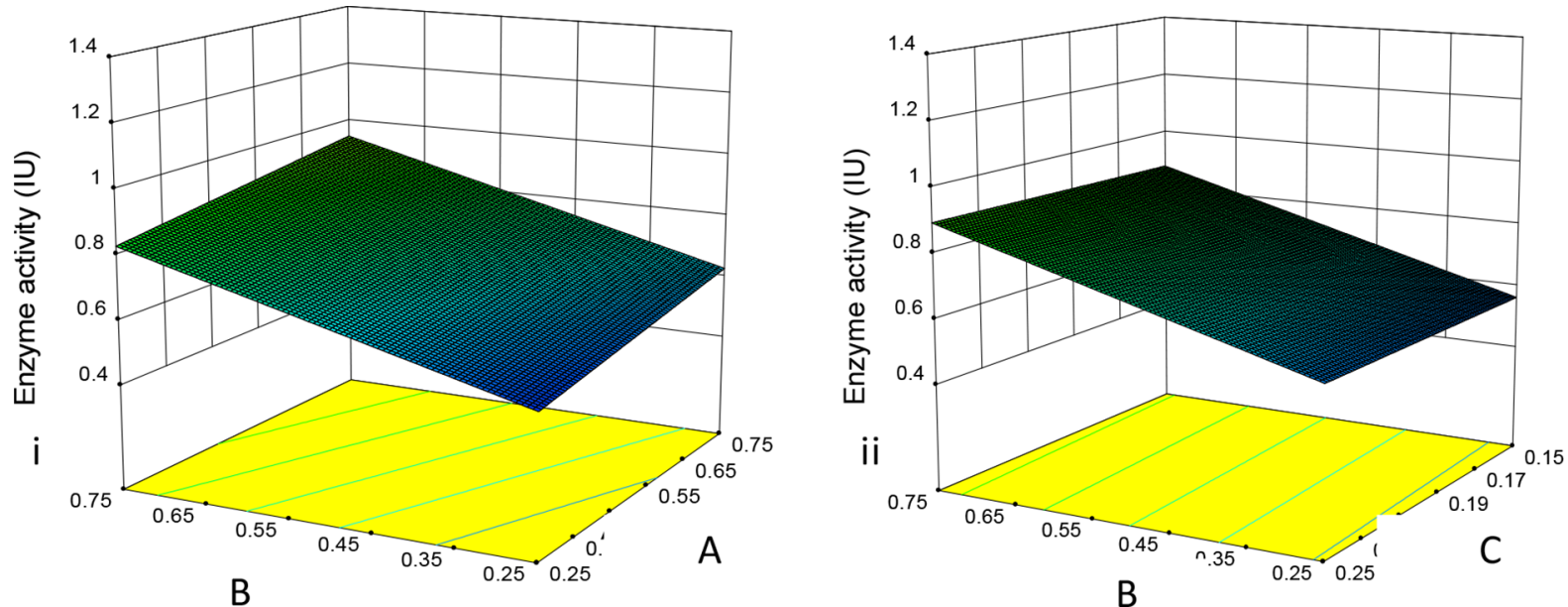

Figure 1. Three-dimensional surface plots for the CCD design employed for L-asparaginase production by $P$. plecoglossicida RS1 using peel extracts from onion and garlic as media supplements to enhance the enzyme activity with parameters: (i) garlic peel vs onion peel and (ii) garlic peel vs $\mathrm{L}^{-}$ asparagine (A: onion peel, B: garlic peel, and C: L-asparagine).

adjusted $R^{2}(0.521)$ value are almost concurrent. Also, the adeq. precision value that measures the signal-to-noise ratio is 9.23 (greater than 4) which is desirable, indicating an adequate signal and that the model is suitable to navigate the design space. Moreover, factor B-garlic peel is identified as significant $(p$-value $<0.05)$ in the CCD experiment performed, which is represented as a linear equation for each of its responses as given below.

$$
\begin{aligned}
\text { Enzyme activity }= & 0.264+0.236 \times \mathrm{A}+0.642 \times \mathrm{B} \\
& +0.13 \times \mathrm{C}
\end{aligned}
$$

where A is the onion peel concn, B is the garlic peel concn, and $\mathrm{C}$ is the $\mathrm{L}$-asparagine concn.
Further, it is clearly seen from the ANOVA that factor Bgarlic peel extract plays a critical role in enzyme production, and this may be owing to the fact that the garlic peel contains more of L-asparagine (20\%) as seen by the HPLC report (Supporting Information, Figure S2). The analysis results are represented in three-dimensional surface plots (Figure 1) which displays a linear relationship between the garlic peel extract and the enzyme activity, though the onion peel extract and Lasparagine did not show a very significant change. The images are representative of the key factors influencing the response based on its $p$-value.

Thus, onion and garlic peels are effective in enhancing the enzyme yields in both methods solid-substrate utilization as well as submerged condition using peel extracts. 


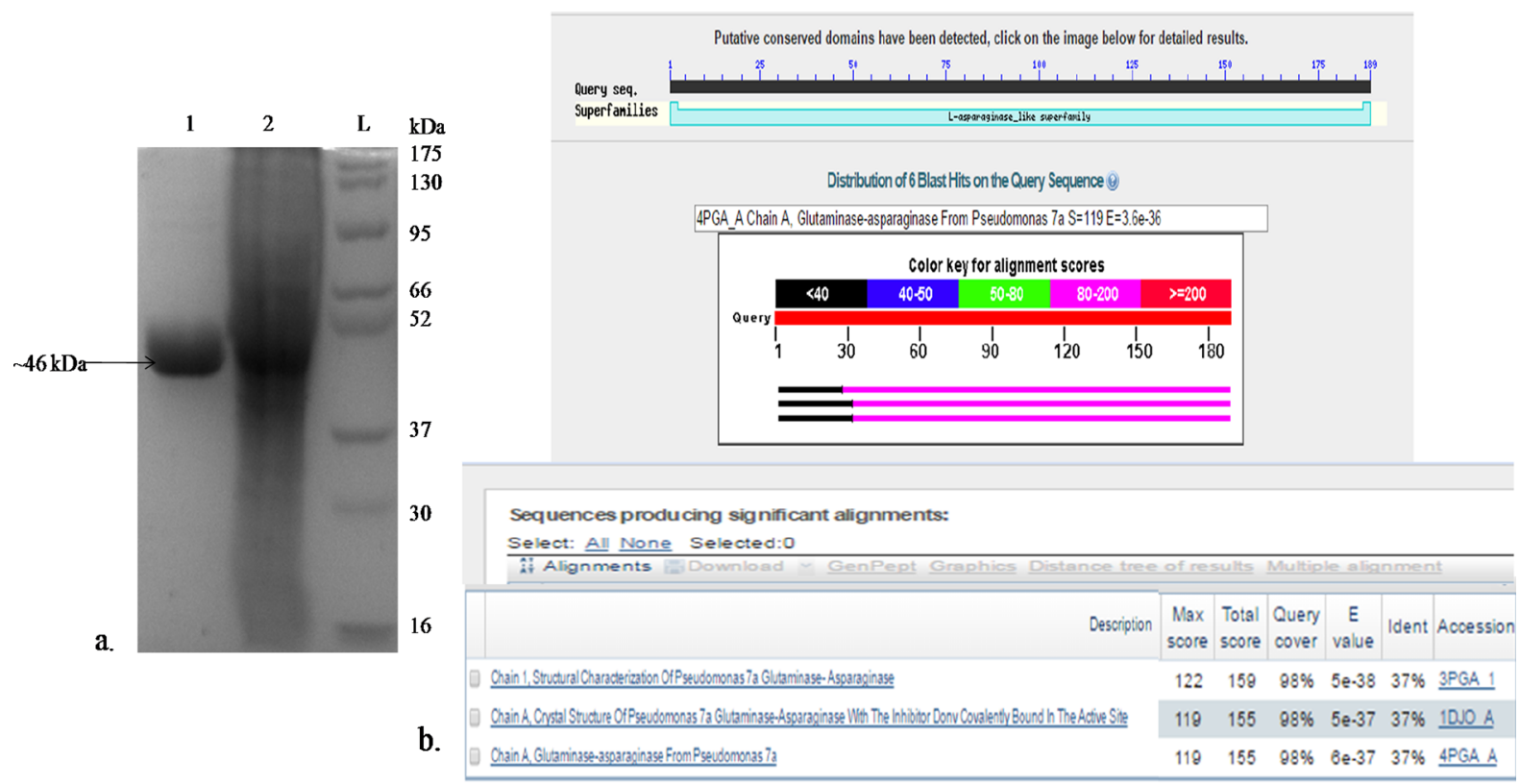

45-SNYTAGKVGVENLVNAVPQLKDIANVK-71

167-GVLVVMNDTVLDGRDVIKTNTTDVATFK SVNYGPLGYIHNGGK-208

219-HTSDTPFDVSKLNELPKVGIVYNYANASDLPAKALVDAGYDGIVSAGVGNGNLYKTVFDTLATAAK-284

c. 295-VPTGATTQDAEVDDAKYGFVASGTLNPQKARVLLQLALTQTKDPQQIQQIFNQY-348

Figure 2. (a) SDS-PAGE analysis of purified L-asparaginase produced using the OG medium by P. plecoglossicida RS1. Lane 1-column-purified Lasparaginase, 2-crude enzyme, and L-ladder. (b) BLAST analysis of peptides obtained on MALDI-TOF analysis of purified L-asparaginase produced by P. plecoglossicida RS1. (c) Peptide sequence obtained by sequencing L-asparaginase produced by P. plecoglossicida RS1.

Validation of the RSM-Optimized OG Medium. The maximum-L-asparaginase-producing RSM run (std. run 12) was replicated with a higher volume $(500 \mathrm{~mL})$ in duplicates, and its responses were recorded and compared with those of the conventional M-9 medium with $0.3 \% \mathrm{~L}$-asparagine without any peel supplement and $2 \%$ inoculum at $\mathrm{pH}$ 6.8. It was observed that the enzyme activity in the optimized media was $1.40 \pm$ $0.04 \mathrm{IU} / \mathrm{mL}$. Similarly, the conventional M-9 medium without supplements showed an enzyme activity of $0.599 \pm 0.02 \mathrm{IU} /$ $\mathrm{mL}$. It is evidenced that the enzyme activity of the AOG optimized medium has increased by 2.3 -fold. Thus, the statistically optimized medium may yield better quantity of enzymes by deploying agro wastes, thus providing waste remediation and industrial economical production of a commercially important enzyme.

Purification and Characterization of L-Asparaginase from the RSM-Optimized OG Medium. The purification process of L-asparaginase from the RSM-optimized OG medium was initiated with centrifugation to separate the culture filtrate containing the extracellular enzyme and the bacteria. Further, precipitation of the protein using ammonium sulfate $(60-80 \%$ saturation) and dialyzing against Tris- $\mathrm{HCl}$ buffer at $\mathrm{pH} 8.6$ were performed to remove the ammonium ions introduced by the addition of ammonium sulfate. The purification summary (Supporting Information, Table S3) shows a higher yield of about $35 \%$, and an enhanced specific activity of about fivefold purification is achieved. This is comparatively a higher yield of enzyme obtained compared to the yield obtained by purifying L-asparaginase from the same isolate using the M-9 medium with $0.8 \%$ industrial effluent. ${ }^{2}$ The size of the subunit of the enzyme was observed to be $\sim 46$ $\mathrm{kDa}$ (Figure 2a) which was the same as reported earlier for $P$. plecoglossicida $\mathrm{RS} 1,{ }^{2}$ and the homogeneity was verified by native and sodium dodecyl sulfate polyacrylamide gel electrophoresis
(SDS-PAGE) analysis. Further, a single band from the native PAGE gel was excised and characterized by matrix-assisted laser desorption ionization time-of-flight (MALDI-TOF) analysis to obtain peptide sequences that showed Mascot top score match with L-asparaginase from the family of Proteobacteria (Supporting Information, Figure S3), the individual sequences were subjected to basic local alignment search tool (BLAST) analysis, and the four short peptide sequences obtained 37\% identity with an existing Pseudomonas 7A (Figure 2b,c). Similar reports of identification of L-asparaginase by MALDI-TOF analysis for the confirmation of the purified protein were given by Kumar and Selvam. ${ }^{20}$ Thus, MALDI-TOF analysis is reliable evidence that confirmed the protein fragments.

Applications of L-Asparaginase. Anticancer Effect of Purified L-Asparaginase Produced by P. plecoglossicida RS1 on HeLa Cell Lines. The anticaner activity of L-asparaginase was studied against human cervical cancer HeLa cell lines. The $\mathrm{IC}_{50}$ of purified L-asparaginase from P. plecoglossicida RS1 was found to be highly effective against the HeLa cell lines $(0.027 \mathrm{IU} / \mathrm{mL})$ in $24 \mathrm{~h}$ of treatment (Supporting Information, Figure S4). The cells showed a complete loss of viability by $36 \mathrm{~h}$ of treatment. This value differs for each cell type, and for HeLa cells, the $\mathrm{IC}_{50}$ value of L-asparaginase from $P$. plecoglossicida RS1 is less than that of L-asparaginase from Salinicoccus sp. M KJ997975 ( IC $_{50}=$ $0.171 \mathrm{IU} / \mathrm{mL}$ ) on HeLa cell lines. ${ }^{21}$ This $\mathrm{IC}_{50}$ value was used for the treatment of HeLa cells for all further studies.

Study of the Effect of Purified L-Asparaginase on Cell Cycle of HeLa Cells. To study the cell cycle effect of purified Lasparaginase on HeLa cells, they were treated with the $\mathrm{IC}_{50}$ value of L-asparaginase determined by the MTT method. Lasparaginase-treated cell line resulted in an increased percentage of cells in the $G_{2}$ phase $(37 \%)$ compared to the untreated control $(3 \%)$ and a decreased $\mathrm{G}_{1}$ phase in treated cells $(43 \%)$ compared to the control (80\%) (Figure 3a). This 


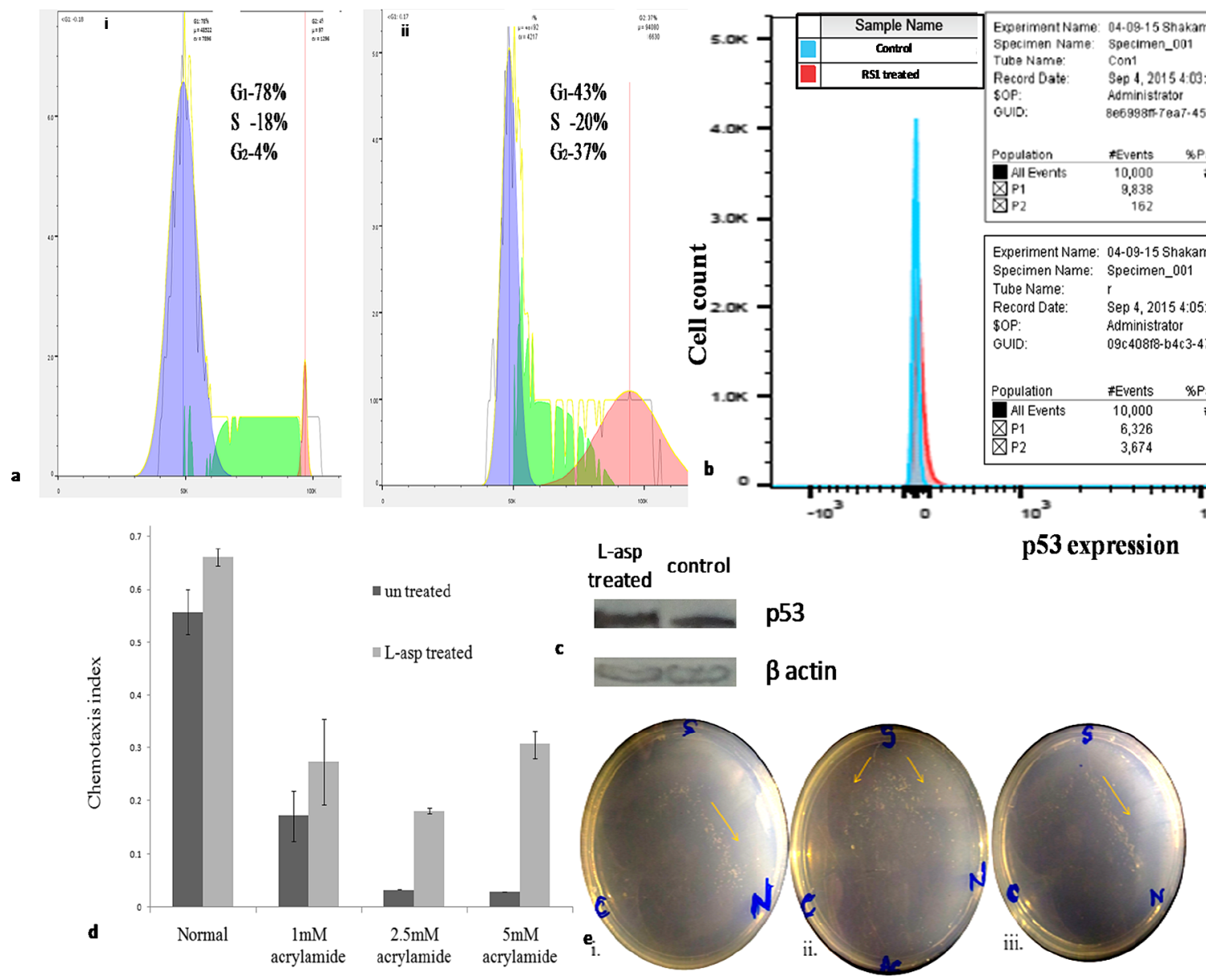

Figure 3. (a) Cell cycle analysis in HeLa cells: (i) control-untreated and (ii) treated with L-asparaginase showing a large number of cells halted at the $G_{2}$ stage. (b) p53 expression in HeLa cells treated with L-asparaginase analyzed by FACS. (c) p53 expression in HeLa cells treated with Lasparaginase analyzed by immunoblotting. (d) Chemotaxis assay performed for the effect of different acrylamide concentrations on C. elegans treated with L-asparaginase as a plot of chemotactic index vs acrylamide concentrations used. (e) Assay plate used to observe the chemotactic behavior of NaCl-starved C. elegans: (i) normal nematodes unexposed to acrylamide, (ii) nematodes exposed to $5 \mathrm{mM}$ acrylamide, and (iii) nematodes coexposed to $5 \mathrm{mM}$ acrylamide and $6 \mathrm{U}$ L-asparaginase.

accumulation at the $G_{2}$ stage in L-asparaginase-treated cells suggests that the enzyme halts the ability of the cells to proceed further to $M$ stage and $G_{2}$ arrest is suggested as the stage of cell death. This may be due to the inadequate supply of $\mathrm{L}$ asparagine which is crucial for protein synthesis to initiate the proceeding of the cells to the $M$ stage and is quenched by Lasparaginase. Such a mechanism of cell arrest is reported for some drugs that can halt cell protein synthesis preceding the $M$ stage. $^{22}$ The observed molecular mechanism of L-asparaginase causing $G_{2}$ arrest in $G_{2}-M$ transition of the cell cycle may further cause a reduction in some regulatory cyclins that regulate $G_{2}-M$ transition, and thus L-asparaginase may be responsible for cell death within $24 \mathrm{~h}$ of treatment, which was also reported and corroborated by the earlier reports. ${ }^{23}$

Study of p53 Expression in HeLa Cells Treated with Purified L-Asparaginase. The expression of p53 in Lasparaginase-treated HeLa cells was observed to be $36.7 \%$ as compared to that in the control (1.6\%) (Figure $3 \mathrm{~b})$. This result is corroborated by the immunoblot analysis (Figure 3c) where the expression of p53 in L-asparaginase-treated HeLa cells is higher compared to that in the untreated control cells. Such an upregulated p53 expression due to the treatment by Lasparaginase was previously evidenced by RT-PCR in human breast cancer MCF-7 and prostate cancer-3 cell lines. ${ }^{24}$
It is well-documented that the tumor suppressor protein p53 is activated in response to DNA damage to protect the normal cells by inducing the transcription of regulatory genes involved in cell cycle, apoptosis, and DNA repair. In most of the cancer types, the p53 gene is mutated or there is a lack of functional p53. ${ }^{25}$ The majority of malignant cervical cancer cells, including human cervical carcinoma ( $\mathrm{HeLa}$ ) cells, contain wild-type p53; however, the rapid degradation of p53 through the ubiquitinproteasome pathway by molecules such as the E6 gene product which interacts with p53 results in similar functional consequences as a mutated p53 gene. ${ }^{26}$ Therefore, although HeLa cells contain a wild-type p53 gene expression, they lack functional p53. However, a low level of leaky transcripts of p53 is seen in untreated HeLa cells which are also reported earlier. ${ }^{27}$ Thus, from the results in this study, it is evident that the p53 expression in HeLa cells has been upregulated by the treatment of L-asparaginase produced by P. plecoglossicida RS1.

To conclude the mechanism of cell cycle arrest and p53 expression studies, L-asparaginase from $P$. plecoglossicida RS1 had shown a $G_{2}$ arrest effect when treated with its $I_{50}$ concentration on HeLa cell lines. L-Asparaginase may have caused severe depletion of proteins required for further DNA synthesis in the $\mathrm{M}$ stage, leading to upregulated $\mathrm{p} 53$, which may have blocked the cells at the $G_{2}$ checkpoint involving the 
inhibition of $\mathrm{Cdc} 2$, the cyclin-dependent kinase required to enter mitosis. Thus, L-asparaginase has an active antiproliferative property on HeLa cells by inducing p53-dependent $G_{2}$ arrest.

Effect of Purified L-Asparaginase in Vitro on Polyacrylamide Inhibition. Acrylamide was declared as a potential carcinogen by IARC in $1994 .^{28}$ The toxic effect of acrylamide is documented in many animal models, and it is reported to be a reproductive and developmental toxicant in male rodents such as rats and mice. ${ }^{29}$ Acrylamides are a degradation product of polyacrylamide, which causes adulteration of soil and/or groundwater systems (Public Health 2003) when it is deposited in soil by anthropogenic ways. The health hazards of acrylamide thus-formed as an environmental pollutant are well-documented, and the model plant Arabidopsis is prospected to study the effect of acrylamide. ${ }^{11}$

In the food industry, specifically potato food products such as french fries, acrylamide is formed as a product of maillard reaction and many ways have been prospected for the inhibition of acrylamide; one of them being used is Lasparaginase, to cleave off $\mathrm{L}$-asparagine residues, thus inhibiting the acrylamide formation. The acrylamide mitigation strategies and their challenges have been extensively studied and demonstrated. ${ }^{9}$

In this study, the use of purified L-asparaginase to inhibit the acrylamide formation in vitro has been documented. It was observed that in the absence of L-asparaginase, polymerization of polyacrylamide occurred at approximately $2.84 \mathrm{~min}$, whereas amide polymerization was delayed up to $25.71 \mathrm{~min}$ when $6 \mathrm{IU} /$ $\mathrm{mL}$ enzyme was used (Table 3 ) which is comparable to the

Table 3. Time Required for the Polymerization of Acrylamide in the Presence of Various Concentrations of $L$ Asparaginase Produced by P. plecoglossicida RS1

$\begin{array}{ccc}\text { no. } & \text { enzyme added }(\mathrm{IU} / \mathrm{mL}) & \text { time in minutes } \\ 1 & 0 & 2.84 \pm 0.28 \\ 2 & 0.75 & 5.83 \pm 0.215 \\ 3 & 1.5 & 7.43 \pm 0.095 \\ 4 & 3 & 15.17 \pm 0.05 \\ 5 & 6 & 25.72 \pm 0.505\end{array}$

previous studies where $3 \mathrm{~mL}$ of crude L-asparaginase produced by Bacillus licheniformis was used. ${ }^{30}$ Thus, this enzyme, which is capable of hydrolyzing the free L-asparagine residues and thus mitigating acrylamide, is of interest in bakery and food industries where polyacrylamide formation is to be avoided.

Effect of L-Asparaginase on Acrylamide-Exposed C. elegans by Chemotaxis Assay. Biological systems can serve as an active indicator of toxicity for many chemical inducers and repressors that are helpful in evaluating their biological efficacy in vivo. C. elegans is one such model organism. Acrylamide toxicity and its effect on chemotaxis plasticity and learning abilities are well-reported. ${ }^{31}$ Acrylamide toxicity in the range of 1-5 $\mathrm{mM}$ has been studied in C. elegans for the effect on its chemotactic index. Further, the effect of xenobiotics on chemotaxis was also studied by Ju et al. ${ }^{32}$

The chemotaxis assay was based on the attraction of $C$. elegans to $\mathrm{NaCl}$; when impaired by acrylamide, the chemotaxis of the nematodes toward $\mathrm{NaCl}$ decreases dramatically. The mitigation of acrylamide by purified L-asparaginase produced by P. plecoglossicida RS1 was studied by the coexposure of $\mathrm{L}$ - asparaginase and acrylamide, which would result in changes in the chemotactic index of $C$. elegans.

L-asparaginase-treated $C$. elegans showed the restoration of chemotactic index compared to untreated C. elegans exposed to acrylamide (Figure 3d). Further, the path of movement of $C$. elegans toward $\mathrm{NaCl}$ in untreated and treated conditions (Figure 3e) shows the restoration of the learning ability and cognitive skills of the nematodes on treatment by Lasparaginase. Thus, it can be concluded that the acrylamide level is indeed alleviated by L-asparaginase, and hence it did not impair the learning ability in C. elegans coexposed to L-asp and acrylamide. Thus, L-asparaginase produced by P. plecoglossicida RS1 can be used for acrylamide mitigation.

\section{CONCLUSIONS}

Agro wastes generated by the discarded peels of onion and garlic were effectively utilized for the economical production of higher yield (2.3-fold) of L-asparaginase by P. plecoglossicida RS1, by employing statistical modeling studies. The enzyme produced using the optimized OG peel media was purified to homogeneity, which was identified and confirmed by MALDI peptide fingerprinting analysis. Moreover, the application of this purified L-asparaginase in cytotoxicity of human cervical cancer cells causing a p53-mediated $G_{2}$ cell cycle arrest was documented. Further, the mitigation of toxicant acrylamide was reported both in vitro and also by utilizing animal model $C$. elegans for the first time by the use of the above purified Lasparaginase. Thus, L-asparaginase produced by P. plecoglossicida RS1 can be a potential candidate for commercial production and applications in both therapeutics and food industry.

\section{MATERIALS AND METHODS}

Bacterial Culture and Conditions for the Production of L-Asparaginase. Marine isolate P. plecoglossicida RS1 (GenBank ID: KJ508408) positive for the production of Lasparaginase was cultivated and maintained using an M-9 agar medium with $0.3 \%$ L-asparagine. Inoculum preparation of $P$. plecoglossicida RS1 was done in a liquid M-9 medium containing $0.3 \%(\mathrm{w} / \mathrm{v})$ L-asparagine; the cell-free supernatant was used as the crude enzyme source. The enzyme activity was calculated using direct Nessler's method ${ }^{33}$ and represented as $\mathrm{IU} / \mathrm{mL}$; the protein was evaluated $(\mathrm{mg} / \mathrm{mL})$ using Lowry's method; and the specific activity was expressed as $\mathrm{IU} / \mathrm{mg}$ of protein.

Production of L-Asparaginase by Agro-Based Waste Supplementation. Onion and Garlic Peels for the Production of L-Asparaginase (Solid-Substrate Utilization). Dried peels of onion and garlic (OG) were sterilized and used directly in the M-9 medium without and with L-asparagine (0.3 $\mathrm{w} / \mathrm{v} \%)$, and P. plecoglossicida RS1 was given as $2 \%$ inoculum. Lasparaginase production was analyzed after $48 \mathrm{~h}$ by estimating the enzyme activity of the culture supernatant used as the crude enzyme.

SEM of OG Peels in the M-9 Medium. The colonization of the onion and garlic peel fragments present by P. plecoglossicida RS1 when grown as submerged culture in the M-9 medium was visualized after $48 \mathrm{~h}$ of incubation by a scanning electron microscope (TESCAN VEGA III, Czech Republic), where peel fragments in the uninoculated medium were used as a control. The peel fragments were sputter-coated with gold particles under vacuum and observed using an accelerated electron beam at $10 \mathrm{kV}$. 
HPLC Analysis of Peel Extracts. Dried and powdered onion and garlic peels were boiled in $0.03 \mathrm{M}$ potassium phosphate monobasic $\mathrm{pH} 3.2$ /acetonitrile (80:20), and the contents were thus extracted. This extract was maintained as a $30 \%$ stock (w/ $\mathrm{v}$ ), sterilized, and used as a supplement for the production of Lasparaginase by $P$. plecoglossicida RS1. The extracts were also analyzed for their L-asparagine content using HPLC, on a C-18 column, where the mobile phase was acetonitrile/0.03 M potassium phosphate, $\mathrm{pH} 3.2$ (20:80), the flow rate was 0.5 $\mathrm{mL} / \mathrm{min}$, the column temperature was $30{ }^{\circ} \mathrm{C}$, and the sample volume injected was $20 \mu \mathrm{L}$. L-Asparagine was detected at 190 nm. ${ }^{34}$

Production of L-Asparaginase by $P$. plecoglossicida RS1 Using Peel Extracts (Submerged Fermentation). Different concentrations of extracts of garlic peel $(0.1-1 \mathrm{v} / \mathrm{v}$ $\%)$ and onion peel $(0.1 \mathrm{~g} / 100 \mathrm{~mL}$ to $1 \mathrm{~g} / 100 \mathrm{~mL})$, prepared from $30 \%$ stock solution mentioned above, along with $0.3 \%$ $(\mathrm{w} / \mathrm{v}) \mathrm{L}$-asparagine or without L-asparagine in the M-9 medium $(30 \mathrm{~mL})$ were used to study the L-asparaginase production. The medium without onion or garlic peel extract with $0.3 \%(\mathrm{w} / \mathrm{v}) \mathrm{L}-$ asparagine was used as a control. The incubation was at static conditions at $37{ }^{\circ} \mathrm{C}$ for $24 \mathrm{~h}$, and L-asparaginase in terms of enzyme activity and protein and specific activity was quantified. This study was performed in triplicate analyses.

Statistical Optimization of the Media Components for the Production of L-Asparaginase by $P$. plecoglossicida RS1 by RSM, Using CCD. To optimize the concentrations of the onion and garlic peel extracts and to analyze their combined effect on the specific activity of L-asparaginase, the CCD was performed using Design-Expert 9 as given below (Table 4).

Table 4. Design Summary of RSM Study for Onion and Garlic Peel Supplementation with L-Asparagine for LAsparaginase Production

\begin{tabular}{ccccccc} 
no. & parameter & $\begin{array}{c}\text { central } \\
\text { value }\end{array}$ & $\begin{array}{c}\text { low values } \\
(-1)\end{array}$ & $\begin{array}{c}\text { high } \\
\text { values } \\
(+1)\end{array}$ & $(-\alpha)$ & $(+\alpha)$ \\
A & $\begin{array}{c}\text { onion peel ext. } \\
\text { (v/v \%) }\end{array}$ & 0.5 & 0.25 & 0.75 & 0.08 & 0.92 \\
B $\quad \begin{array}{c}\text { garlic peel ext. } \\
\text { (v/v \%) }\end{array}$ & 0.5 & 0.25 & 0.75 & 0.08 & 0.92 \\
C & L-asparagine & 0.2 & 0.15 & 0.25 & 0.11 & 0.28 \\
\hline
\end{tabular}

According to this design, the total number of treatment combinations is $2^{k}+2 k+n_{0}$, where ' $k$ ' is the number of independent variables and $n_{0}$ is the number of replications of the experiments at the central point. Accordingly, a design was formulated, which comprised three factors, namely, onion peel extract, garlic peel extract, and L-asparagine with six replicates at the central value. Further, each run was performed in triplicates, the influence of each component was evaluated at five coded levels, and responses were evaluated as enzyme activity (IU/ $\mathrm{mL}$ ). Such a design with three values was formulated for the RSM study of the same isolate. ${ }^{35}$ The relationship between the different component factors can be established as a linear or quadratic equation.

The medium composition that gave the best enzyme yield was validated further.

Validation of the Optimized Medium. The optimized concentration of the individual peel (OG) obtained by CCD was validated in the $\mathrm{M}-9$ medium up to $500 \mathrm{~mL}$, inoculated with $2 \%(\mathrm{v} / \mathrm{v})$ inoculum of $P$. plecoglossicida, and incubated at $37{ }^{\circ} \mathrm{C}$ for $24 \mathrm{~h}$ in static conditions. The yield in terms of enzyme activity was calculated. The study was carried out in duplicates, and the mean value was calculated.

Purification and Characterization of the Enzyme. The peels and the inoculum P. plecoglossicida were separated from the broth by centrifugation at $10000 \mathrm{rpm}$ for $10 \mathrm{~min}$. Further, the purification was performed in a stepwise manner by ammonium sulfate (HiMedia) precipitation (stepwise saturation from 20 to $80 \%$ saturation with $20 \%$ increments) and dialysis (against $50 \mathrm{mM}$ Tris- $\mathrm{HCl}$ buffer of $\mathrm{pH} 8.6$ in a dialysis membrane-110, HiMedia, carried out at $4{ }^{\circ} \mathrm{C}$ ), and the column purification of the protein was done at $18{ }^{\circ} \mathrm{C}$. The dialyzed protein fraction was then further applied on diethylaminoethyl sepharose column (bed volume of $30 \mathrm{~mL}$ ) and purified to homogeneity. The chromatographic purifications were analyzed for the protein at $280 \mathrm{~nm}$ (BioPhotometer D30, Eppendorf, Germany). ${ }^{35}$ The purified fractions of L-asparaginase were pooled and dialyzed with Tris- $\mathrm{HCl}(50 \mathrm{mM}$ and $\mathrm{pH} 8.6)$ and were stored at $-20{ }^{\circ} \mathrm{C}$ which were further used to identify the molecular weight of L-asparaginase by SDS-PAGE. ${ }^{36}$ The purity of L-asparaginase was determined using the standard molecular weight markers of SDS-PAGE (GeneDireX-BLUltra prestained protein marker).

Characterization of Purified L-Asparaginase by MALDI-TOF Analysis. MALDI-TOF/TOF MS analyses were performed using a Bruker Daltonics ULTRAFLEX III (USA). The single band of purified protein L-asparaginase from native PAGE gel was excised to small pieces, which were destained until they become translucent white. The gels were dehydrated using acetonitrile, vacuum-dried, then rehydrated with dithiothreitol (DTT), and incubated for $1 \mathrm{~h}$. After that, the DTT solution was removed, and the gel pieces were subjected to iodoacetamide for $45 \mathrm{~min}$. After incubation, the supernatant was removed and ammonium bicarbonate solution was added and kept for $10 \mathrm{~min}$. The supernatant was again removed, and the gel was dehydrated with acetonitrile until complete dryness. The gel was trypsinized overnight, and the digested solution was transferred to fresh Eppendorf tubes, where the gel pieces were extracted after washing and the removed supernatant was further collected each time into a fresh Eppendorf and vacuumdried. The dried peptide mixture was suspended in Tris-acetate buffer and was mixed with a HCCA matrix in 1:1 ratio, and from the resulting solution, $2 \mu \mathrm{L}$ was spotted onto the MALDI plate. After air drying, the sample was analyzed on the MALDITOF/TOF ULTRAFLEX III instrument and further analyzed with Flex Analysis Software for obtaining the peptide mass fingerprint. The masses obtained in the peptide mass fingerprint were submitted for Mascot search in "concerned" database for the identification of the protein. The peptide fragment obtained was also subjected to BLAST analysis to identify the protein.

Application of Purified L-Asparaginase as a Anticancer Agent for Human Cervical Cancer Cells (HeLa Cell Line). The purified L-asparaginase from $P$. plecoglossicida RS1 was tested for anticancer property on human cervical cells of HeLa cell lines grown in Dulbecco's modified Eagle's medium (DMEM) (high glucose) (HiMedia, India) supplemented with $10 \%$ fetal bovine serum (FBS) and $1 \%$ antibiotic penicillin/streptomycin mixture, seeded on 96 -well plates $(1 \times$ $10^{4}$ cells/well), and incubated at $37{ }^{\circ} \mathrm{C}$ in a $5 \% \mathrm{CO}_{2}$ humidified atmosphere. After attaining confluence $(12 \mathrm{~h})$, the cells were treated with purified L-asparaginase $(0.005-0.4 \mathrm{IU} / \mathrm{mL})$ produced by P. plecoglossicida RS 1 at $37^{\circ} \mathrm{C}$ and standard cell culture conditions and incubated up to $36 \mathrm{~h}$. The untreated 
HeLa cells and blank medium were kept as a control. MTT was performed as per the MTT assay kit (HiMedia, India). The toxic concentration, that is, $\mathrm{IC}_{50}$ was calculated. $\mathrm{IC}_{50}$ is a drug concentration which inhibits the growth of cells by $50 \%$ relative to an untreated control.

Cell Cycle Analysis of HeLa Cells Treated with the Purified L-Asparaginase. To study the effect of Lasparaginase treatment on the cell cycle of HeLa cells, $1 \times$ $10^{6} \mathrm{HeLa}$ cells were seeded in 12-well plates and grown in DMEM (HiMedia, India) supplemented with $10 \%$ FBS for $24 \mathrm{~h}$ under standard cell culture conditions. After the cells attained $80 \%$ confluence, six wells were treated with purified Lasparaginases produced by $P$. plecoglossicida RS1 and the remaining six wells were kept untreated as a control and incubated at $37{ }^{\circ} \mathrm{C}$ in a $5 \% \mathrm{CO}_{2}$ humidified atmosphere. Post $24 \mathrm{~h}$ of incubation, the cells were trypsinized, fixed, treated with propidium iodide, and analyzed by flow cytometry (BD FACSAria III, BD Biosciences, USA). FlowJo software was used for data analysis and to discriminate the cell cycle phases. $^{35}$

Study of p53 Expression in Purified-L-AsparaginaseTreated HeLa Cells by Flow Cytometry Analysis. Untreated HeLa cells and cells treated with L-asparaginase were subjected to primary antibody p53 mouse monoclonal IgG (Santa Cruz F2513), followed by secondary antibody, Alexa Fluor 488 goat antimouse IgG $(\mathrm{H}+\mathrm{L})$ cat no. A11001 (Invitrogen, Life Technologies, USA). The event of expression of p53 in treated cells in comparison with control cells was analyzed using flow cytometry (BD FACSAria III, BD Biosciences, USA) and FlowJo software and expressed as percentage.

Immunoblot Analysis of L-Asparaginase-Treated HeLa Cells. HeLa cells were seeded in a 12-well plate, 6 wells containing HeLa were left untreated, and remaining 6 wells were treated with L-asparaginase purified from P. plecoglossicida RS1. After $24 \mathrm{~h}$ of incubation in standard cell culture conditions, the cells were scrapped and the protein was extracted using $300 \mu \mathrm{L}$ of lysis buffer [Tris-HCl-50 mM, $\mathrm{NaCl}-150 \mathrm{mM}$, Triton-X-1\%, sodium deoxycholate $0.5 \%$, SDS $0.1 \%$, DTT $-1 \mathrm{mM}$, PMSF-0.1\%, protease inhibitor cocktail-1X (HiMedia, India)] and incubated in ice for $1 \mathrm{~h}$, with intermittent vortexing. After $1 \mathrm{~h}$ of incubation, the mixture was centrifuged at $12000 \mathrm{rpm}$ for $20 \mathrm{~min}$, the supernatant was preserved as a total cell protein, and the pellet was discarded. For immunoblot analysis, $50 \mu \mathrm{g}$ of protein was loaded per lane in SDS-PAGE gel, separated elecrtophoretically, and electroblotted using a poly(vinylidene difluoride) membrane in transfer buffer containing 20\% (v/v) methanol, $192 \mathrm{mM}$ glycine, and $25 \mathrm{mM}$ Tris at $\mathrm{pH} 8.3$ at $90 \mathrm{mV}$ for $90 \mathrm{~min}$. Nonspecific binding sites on the membrane were blocked with $5 \%$ skimmed milk for $60 \mathrm{~min}$. The membrane was then treated with monoclonal antibody specific to human p53 (Santa Cruz F2513), diluted to 1:1000, and was then incubated overnight. Further, the membrane was washed with Tris buffer salineTWEEN 20 (TBS-T) and incubated with horseradish peroxidase-conjugated secondary antibody specific to p53 monoclonal antibody (Santa Cruz SC-2005) for $1 \mathrm{~h}$. Thereafter, the membrane was washed with TBS-T, and the presence of p53 was visually detected on the membrane by the addition of developing solutions, solution-1-12 mg of DAB $\left(3,3^{\prime}, 4,4^{\prime}\right.$ tetra amino biphenyl tetra hydrochloride), a colored substrate made in $18 \mathrm{~mL}$ of $0.05 \mathrm{M}$ Tris- $\mathrm{HCl} \mathrm{pH} \mathrm{7.5,} \mathrm{along} \mathrm{with} 2 \mathrm{~mL}$ of solution- 2 made of $0.3 \% \mathrm{NiCl}_{2}$ and $0.3 \% \mathrm{H}_{2} \mathrm{O}_{2}$. All steps were carried out at $20^{\circ} \mathrm{C}$. The molecular weight of the protein bands was calculated by comparison with an SDS-PAGE marker (GeneDireX, Taiwan).

Application of the Purified L-Asparaginase for the Degradation of Acrylamide. In Vitro Study of Acrylamide Degradation by L-Asparaginase Purified from P. plecoglossicida RS1. Inhibition of polyacrylamide formation using Lasparaginase produced by $P$. plecoglossicida RS1 was demonstrated by standard methods in vitro as described by Shakambari et al. and Mahajan et al. ${ }^{30,35}$ The time taken for the polymerization of acrylamide solution was noted for different concentrations of L-asparaginase used.

Demonstration of the Effect of Acrylamide Mitigation by L-Asparaginase Using C. elegans as a Live Animal Model. Chemotaxis assay was carried out modifying a method described previously by Saeki et al. ${ }^{37}$ Accordingly, C. elegans ( $n=200$ per replicate; three replicates per group) was exposed $(48 \mathrm{~h})$ to $5 \mathrm{~mL}$ of sublethal concentrations of acrylamide $(0,1$, 2.5 , and $5 \mathrm{mM}$ ) as reported previously by Ju et al. in the six-well plates for $48 \mathrm{~h}$ at $20{ }^{\circ} \mathrm{C}$. ${ }^{32}$ Another set of nematodes was exposed to acrylamide $(0,1,2.5$, and $5 \mathrm{mM})$ along with Lasparaginase $(6 \mathrm{U})$ for $48 \mathrm{~h}$ under aforementioned conditions. After $48 \mathrm{~h}$ of exposure, M-9 buffer was used to wash the nematodes and the nematode groups were further starved for $\mathrm{NaCl}$ for $3 \mathrm{~h}$ in $\mathrm{M}-9$ buffer. After $3 \mathrm{~h}$, the nematodes were transferred to the assay plates ( $5 \mathrm{mM} \mathrm{K}$ phosphate, $\mathrm{pH} 6.0,1$ $\mathrm{mM} \mathrm{CaCl}_{2}, 1 \mathrm{mM} \mathrm{MgSO}_{4}$, and $20 \mathrm{~g} / \mathrm{L}$ agar), and three points were marked equidistant from each other as vertices of a triangle, as $\mathrm{S}$ - starting point, $\mathrm{N}-\mathrm{NaCl}+\mathrm{NaN}_{3}, \mathrm{C}-$ control $\left(\mathrm{NaN}_{3}\right.$ alone). Nematodes were transferred to the $\mathrm{S}$ point of the plate and incubated for $30 \mathrm{~min}$ at $20^{\circ} \mathrm{C}$. After $30 \mathrm{~min}$, the nematodes were anesthetized by the presence of $\mathrm{NaN}_{3}$, and the numbers of nematodes at the zone with $\mathrm{NaCl}$ and those without $\mathrm{NaCl}$ were counted for each group. The chemotactic index was calculated by the formula (the number within the $\mathrm{NaCl}$ gradient - the number within the control)/the total number of animals on the plate. ${ }^{37}$

\section{ASSOCIATED CONTENT}

\section{Supporting Information}

The Supporting Information is available free of charge on the ACS Publications website at DOI: 10.1021/acsomega.7b01429.

SEM of peels, HPLC of peel extracts, MALDI analysis of pure L-asparaginase, L-asp cytotoxicity by MTT on HeLa cells, screening agro wastes for L-asp production, ANOVA analysis, and purification summary of Lasparaginase (PDF)

\section{AUTHOR INFORMATION}

\section{Corresponding Author}

*E-mail: vara5277@gmail.com (P.V.).

ORCID

Perumal Varalakshmi: 0000-0002-5420-4688

\section{Author Contributions}

P.V. designed the experiments; G.S. and R.S.K. conducted the experiments; P.V. and B.A. analyzed the data; and G.S. and P.V. wrote the manuscript. All authors revised the manuscript. All authors have given approval to the final version of the manuscript.

Notes

The authors declare no competing financial interest. 


\section{ACKNOWLEDGMENTS}

The authors thank the DST-SERB-SB/EMEQ-128/2013, date of sanction 28.10.2013, for the financial support to P.V. and CSIR-UGC (no. 17-06/2012(i) EU-V) fellowship to G.S. Also, the help of DST-PURSE instrumentation facility, DST-FIST, School of Biological Sciences, Madurai Kamaraj University, for FACS facility is duly acknowledged.

\section{REFERENCES}

(1) Arun, C.; Sivashanmugam, P. Identification and optimization of parameters for the semi-continuous production of garbage enzyme from pre-consumer organic waste by green RP-HPLC method. Waste Manage. 2015, 44, 28-33.

(2) Shakambari, G.; Sumi, B. M.; Ashokkumar, B.; Palanivelu, P.; Varalakshmi, P. Industrial effluent as a substrate for glutaminase free Lasparaginase production from Pseudomonas plecoglossicida strain RS1; media optimization, enzyme purification and its characterization. RSC Adv. 2015, 5, 48729-48738.

(3) Makky, E. A.; Loh, Y. C.; Karim, M. R. Purification and partial characterization of a low molecular weight $\mathrm{L}$-asparaginase produced from corn cob waste. Biocatal. Agric. Biotechnol. 2014, 3, 265-270.

(4) Bhattacharyya, P.; Chakrabarti, K.; Tripathy, S.; Chakraborty, A.; Kim, K.; Kim, S. H. L-asparaginase and L-glutaminase activities in submerged rice soil amended with municipal solid waste compost and decomposed cow manure. J. Environ. Sci. Health, Part B 2007, 42, 593-598.

(5) Broome, J. D. Studies on the mechanism of tumor inhibition by L-asparaginase: Effects of the enzyme on asparagine levels in the blood, normal tissues, and 6C3HED lymphomas of mice: differences in asparagine formation and utilization in asparaginase-sensitive and -resistant lymphoma cells. J. Exp. Med. 1968, 127, 1055-1072.

(6) Boyse, E. A.; Old, L. J.; Campbell, H. A.; Mashburn, L. T. Suppression of murine Leukemias By L-asparaginase: Incidence of sensitivity among leukemias of various types: comparative inhibitory activities of guinea pig serum L-asparaginase and Escherichia coli Lasparaginase. J. Exp. Med. 1967, 125, 17-31.

(7) Biagiotti, S.; Paoletti, M. F.; Fraternale, A.; Rossi, L.; Magnani, M. Drug delivery by red blood cells. IUBMB Life 2011, 63, 621-631.

(8) Abbas, A. A.; Sabbah, M. A.; Kathum, O. A. Partial purification and cytotoxic activity of L-asparaginase isolated from Escherichia coli. Iraqi J. Sci. 2010, 51, 290-294.

(9) Vinci, M. R.; Mestdagh, F.; Van Poucke, C.; Kerkaert, B.; de Muer, N.; Denon, Q.; Van Peteghem, C.; de Meulenaer, B. Implementation of acrylamide mitigation strategies on industrial production of French fries: challenges and pitfalls. J. Agric. Food Chem. 2011, 59, 898-906.

(10) Hendriksen, H. V.; Kornbrust, B. A.; Østergaard, P. R.; Stringer, $M$. A. Valuating the potential for enzymatic acrylamide mitigation in a range of food products using an asparaginase from Aspergillus oryzae. J. Agric. Food Chem. 2009, 57, 4168-4176.

(11) Gao, J.-J.; Peng, R.-H.; Zhu, B.; Wang, B.; Wang, L.-J.; Xu, J.; Sun, M.; Yao, Q.-H. Phytoremediation potential of Arabidopsis with reference to acrylamide and microarray analysis of acrylamide-response genes. Ecotoxicol. Environ. Saf. 2015, 120, 360-368.

(12) Mishra, A. Production of L-asparaginase, an anticancer agent, from Aspergillus niger using agricultural waste in solid state fermentation. Appl. Biochem. Biotechnol. 2006, 135, 33-42.

(13) Ayyachamy, M.; Khelawan, K.; Pillay, D.; Permaul, K.; Singh, S. Production of inulinase by Xanthomonas campestris pv phaseoli using onion (Allium cepa) and garlic (Allium sativum) peels in solid state cultivation. Lett. Appl. Microbiol. 2007, 45, 439-444.

(14) Sharma, K.; Mahato, N.; Nile, S. H.; Lee, E. T.; Lee, Y. R. Economical and environmentally-friendly approaches for usage of onion (Allium cepa L.) waste. Food Funct. 2016, 7, 3354-3369.

(15) Saka, C.; Şahin, Ö.; Demir, H.; Kahyaoğlu, M. Removal of Lead(II) from Aqueous Solutions using Pre-boiled and FormaldehydeTreated Onion Skins as a New Adsorbent. Sep. Sci. Technol. 2011, 46, 507-517.
(16) Alberto, M. R.; de Nadra, M. C. M.; Arena, M. E. Influence of phenolic compounds on the growth and arginine deiminase system in a wine lactic acid bacterium. Braz. J. Microbiol. 2012, 43, 167-176.

(17) Jones, M. G.; Hughes, J.; Tregova, A.; Milne, J.; Tomsett, A. B.; Collin, H. A. Biosynthesis of the flavour precursors of onion and garlic. J. Exp. Bot. 2004, 55, 1903-1918.

(18) Liakopoulou-Kyriakides, M.; Sinakos, Z.; Kyriakidis, D. A. Identification of alliin, a constituent of allium cepa with an inhibitory effect on platelet aggregation. Phytochemistry 1985, 24, 600-601.

(19) Yuan, Y. Z.; Gu, J.; Hang, T. J.; Chen, J.; Zhang, Z. X. [Related substances in purified alliin determined by HPLC-MS/MS]. Yaoxue Xuebao 2007, 42, 639-642.

(20) Kumar, M. S.; Selvam, K. Isolation and Purification of High Efficiency L-asparaginase by Quantitative Preparative Continuouselution SDS PAGE Electrophoresis. J. Microb. Biochem. Technol. 2011, 3, 073-083.

(21) Bhat, M.; Marar, T. Cytotoxic Effect of Purified L-asparaginase from Salinicoccus sp. M KJ997975. Int. J. Curr. Microbiol. Appl. Sci. 2015, 4, 701-712.

(22) Scotti, C.; Sommi, P.; Pasquetto, M. V.; Cappelletti, D.; Stivala, S.; Mignosi, P.; Savio, M.; Chiarelli, L. R.; Valentini, G.; BolanosGarcia, V. M.; Merrell, D. S.; Franchini, S.; Verona, M. L.; Bolis, C.; Solcia, E.; Manca, R.; Franciotta, D.; Casasco, A.; Filipazzi, P.; Zardini, E.; Vannini, V. Cell-cycle inhibition by Helicobacter pylori Lasparaginase. PLoS One 2010, 5, No. e13892.

(23) Husain, I.; Sharma, A.; Kumar, S.; Malik, F. Purification and characterization of glutaminase free asparaginase from Pseudomonas otitidis: Induce apoptosis in human leukemia MOLT-4 cells. Biochimie 2016, 121, 38-51.

(24) Mohamed, H. F. Molecular investigation and anticancer properties of purified L-Asparaginase from E. coli isolate against, CaCo2, MCF7 and PC3 cell lines. Am. J. PharmTech Res. 2014, 4, $308-322$.

(25) Zilfou, J. T.; Lowe, S. W. Tumor suppressive functions of $\mathrm{p} 53$. Cold Spring Harbor Perspect. Biol. 2009, 1, a001883.

(26) Hoppe-Seyler, F.; Butz, K. Repression of endogenous p53 transactivation function in HeLa cervical carcinoma cells by human papillomavirus type $16 \mathrm{E} 6$, human $\mathrm{mdm}-2$, and mutant p53. J. Virol. 1993, 67, 3111-3117.

(27) Hietanen, S.; Lain, S.; Krausz, E.; Blattner, C.; Lane, D. P. Activation of p53 in cervical carcinoma cells by small molecules. Proc. Natl. Acad. Sci. U. S. A. 2000, 97, 8501-8506.

(28) IARC. Acrylamide; International Agency for Research on Cancer: Lyon, France, 1994.

(29) Sakamoto, J.; Hashimoto, K. Reproductive toxicity of acrylamide and related compounds in mice-effects on fertility and sperm morphology. Arch. Toxicol. 1986, 59, 201-205.

(30) Mahajan, R. V.; Saran, S.; Kameswaran, K.; Kumar, V.; Saxena, R. K. Efficient production of L-asparaginase from Bacillus licheniformis with low-glutaminase activity: optimization, scale up and acrylamide degradation studies. Bioresour. Technol. 2012, 125, 11-16.

(31) Li, J.; Li, D.; Yang, Y.; Xu, T.; Li, P.; He, D. Acrylamide induces locomotor defects and degeneration of dopamine neurons in Caenorhabditis elegans. J. Appl. Toxicol. 2016, 36, 60-67.

(32) Ju, J.; Saul, N.; Kochan, C.; Putschew, A.; Pu, Y.; Yin, L.; Steinberg, C. Cyanobacterial xenobiotics as evaluated by a Caenorhabditis elegans neurotoxicity screening test. Int. J. Environ. Res. Public Health 2014, 11, 4589-4606.

(33) Mashburn, L. T.; Wriston, J. C., Jr. Tumor inhibitory effect of 1asparaginase from Escherichia coli. Arch. Biochem. Biophys. 1964, 105, 450-453.

(34) Bai, C.; Reilly, C. C.; Wood, B. W. Identification and quantitation of asparagine and citrulline using high-performance liquid chromatography (HPLC). Anal. Chem. Insights 2007, 2, 31-36.

(35) Shakambari, G.; Birendranarayan, A. K.; Lincy, M. J. A.; Rai, S. K.; Ahamed, Q. T.; Ashokkumar, B.; Saravanan, M.; Mahesh, A.; Varalakshmi, P. Hemocompatible glutaminase free L-asparaginase from marine Bacillus tequilensis PV9W with anticancer potential modulating p53 expression. RSC Adv. 2016, 6, 25943-25951. 
(36) Laemmli, U. K. Cleavage of structural proteins during the assembly of the head of bacteriophage T4. Nature 1970, 227, 680685.

(37) Saeki, S.; Yamamoto, M.; Iino, Y. Plasticity of chemotaxis revealed by paired presentation of a chemoattractant and starvation in the nematode Caenorhabditis elegans. J. Exp. Biol. 2001, 204, 17571764. 